\title{
Prenatal bisphenol a exposure and dysregulation of infant hypothalamic- pituitary-adrenal axis function: findings from the APrON cohort study
}

Gerald F Giesbrecht ${ }^{1,2^{*}}$, Maede Ejaredar ${ }^{2}$, Jiaying Liu ${ }^{3}$, Jenna Thomas ${ }^{4}$, Nicole Letourneau ${ }^{1,5}$, Tavis Campbell ${ }^{4}$, Jonathan W Martin ${ }^{3}$, Deborah Dewey ${ }^{1,2}$ and the APrON Study Team

\begin{abstract}
Background: Animal models show that prenatal bisphenol A (BPA) exposure leads to sexually dimorphic disruption of the neuroendocrine system in offspring, including the hypothalamic-pituitary-adrenal (HPA) neuroendocrine system, but human data are lacking. In humans, prenatal BPA exposure is associated with sex-specific behavioural problems in children, and HPA axis dysregulation may be a biological mechanism. The objective of the current study was to examine sex differences in associations between prenatal maternal urinary BPA concentration and HPA axis function in 3 month old infants.

Methods: Mother-infant pairs $(n=132)$ were part of the Alberta Pregnancy Outcomes and Nutrition study, a longitudinal birth cohort recruited (2010-2012) during pregnancy. Maternal spot urine samples collected during the 2nd trimester were analyzed for total BPA and creatinine. Infant saliva samples collected prior to and after a blood draw were analyzed for cortisol. Linear growth curve models were used to characterize changes in infant cortisol as a function of prenatal BPA exposure.

Results: Higher maternal BPA was associated with increases in baseline cortisol among females ( $\beta=0.13 \mathrm{log} \mu \mathrm{g} / \mathrm{dL}$; 95\% Cl: 0.01, 0.26), but decreases among males ( $\beta=-0.22 \log \mu \mathrm{g} / \mathrm{dL} ; 95 \% \mathrm{Cl}:-0.39,-0.05)$. In contrast, higher BPA was associated with increased reactivity in males ( $\beta=.30 \mathrm{log} \mu \mathrm{g} / \mathrm{dL} ; 95 \% \mathrm{Cl}: 0.04,0.56$ ) but decreased reactivity in females $(\beta=-0.15 \log \mu \mathrm{g} / \mathrm{dL} ; 95 \% \mathrm{Cl}:-0.35,0.05)$. Models adjusting for creatinine yielded similar results.

Conclusions: Prenatal BPA exposure is associated with sex-specific changes in infant HPA axis function. The biological plausibility of these findings is supported by their consistency with evidence in rodent models. Furthermore, these data support the hypotheses that sexually dimorphic changes in children's behaviour following prenatal BPA exposure are mediated by sexually dimorphic changes in HPA axis function.
\end{abstract}

Keywords: Bisphenol-A, Fetal exposure, Cortisol, Hypothalamic-pituitary-adrenal axis, Infant stress reactivity

\footnotetext{
* Correspondence: ggiesbre@ucalgary.ca

'Department of Paediatrics, University of Calgary, 2500 University Drive,

Calgary, AB T2N 1N4, Canada

${ }^{2}$ Department of Community Health Sciences, University of Calgary, Calgary,

$\mathrm{AB}$, Canada

Full list of author information is available at the end of the article
} 


\section{Background}

Bisphenol A (BPA) is the building block of polycarbonate plastics used to produce a wide range of consumer products including epoxy resins, thermal paper, and dental composites. Numerous rodent studies have shown that fetal/ neonatal exposure to relatively low levels of BPA may result in reproductive and developmental effects, including disruption of sexual differentiation in the brain [31, 45]. These effects have led to the classification of BPA as an endocrine disruptor. Whereas the effects of perinatal BPA exposure on the development of estrogen neuroendocrine systems has been investigated extensively [37-39], the potential effect of BPA exposure on the development of the hypothalamic-pituitary-adrenal (HPA) neuroendocrine system has only recently been investigated in computer and rodent models [13, 40, 42, 43]. In this study, we provide the first human data demonstrating an association between maternal urinary total BPA concentrations during pregnancy and infant HPA axis function.

BPA is among the highest production chemicals worldwide [2], and biomonitoring studies have shown that it is commonly detected (> 82\%; median concentration $0.6-$ $2.6 \mathrm{ng} / \mathrm{mL}$ ) in the urine of pregnant women in the USA, Canada, Mexico, and Europe [1, 9, 10, 14, 33, 47, 57]. In its report on the potential adverse reproductive and developmental effects of BPA, the National Toxicology Program at the National Institute of Environmental Health expressed concern regarding the potential effects of maternal BPA exposure on brain development and behavior in fetuses, infants and children [12]. Maternal BPA can cross the placenta into umbilical circulation $[3,32,51]$ and enters breast milk [59], representing multiple pathways by which maternal BPA exposure may disrupt brain development and behavior in fetuses and infants.

Accumulating evidence suggests that prenatal BPA exposure is associated with symptoms of anxiety, depressed mood, aggression, and hyperactivity in children [18]. However, the mechanisms by which BPA exposure is associated with these behavioural outcomes are not known. The HPA axis is a potential mechanism because it mediates many effects of early life exposure on development [17], and has recently garnered some attention in relation to prenatal BPA exposure. In silico (computer) modeling has shown that BPA can bind to glucocorticoid receptors similarly to other agonists (DEXA and cortisol) [43], suggesting that BPA may be able to directly stimulate the HPA axis. Animal studies, primarily in rodents, show that prenatal BPA exposure (oral administration of $40 \mu \mathrm{g} / \mathrm{kg}$ of the dam's bodyweight/day) increases basal HPA axis secretion of corticosterone in female offspring and increases HPA axis reactivity to a stressor in both males and females, with males showing significantly higher reactivity compared to females $[40,42]$. Chen and colleagues [13] demonstrated that changes in HPA axis function consequent to prenatal BPA exposure mediated the effects of BPA on anxiety/depression-like behaviours in offspring. Taken together, these findings suggest that prenatal exposures to BPA may have both direct and indirect effects on the developing HPA axis and that such effects may contribute to symptoms of anxiety, depressed mood, aggression, and hyperactivity in children. Nevertheless, human data are lacking.

Recently, our research group published the first human data on the association between maternal urinary total BPA concentrations and HPA axis function [21]. This study discovered an association between BPA exposure and dysregulation of the maternal HPA axis. Specifically, higher maternal urinary total BPA concentrations during pregnancy were associated with reduced cortisol (the end product of the HPA axis in humans) at morning awakening and a flatter diurnal cortisol slope. Building upon this work, in the current study we examined the association between maternal urinary BPA concentration during pregnancy and infant HPA axis reactivity to a stressor. We hypothesized that higher maternal urinary total BPA concentrations during pregnancy are associated with changes in baseline and reactivity function of the HPA axis in infants. We furthermore hypothesized that these associations are sex-specific. To achieve these aims, maternal urinary total BPA concentration was measured during pregnancy and infant cortisol reactivity was assessed at 3 months of age.

\section{Methods}

\section{Source population}

Participants were 132 women enrolled in an ongoing prospective birth cohort study, the Alberta Pregnancy Outcomes and Nutrition (APrON) study $(n=2200)$, which is a community sample of volunteers recruited between 2010 and 2012. A full description of the APrON study is available elsewhere [29]. For the current analyses, women were included if they had a singleton pregnancy, were less than 27 weeks of gestation at the first study visit, were 18 years of age or older, participated in infant saliva collection at 3-months of age, and provided a second trimester urine sample. Mother-infant pairs were excluded if the mother smoked or consumed alcohol during pregnancy, or if the mother or infant were being treated with a synthetic glucocorticoid. Because of limited funding, a convenience sample of women in the full cohort was enrolled in saliva collection $(n=290)$ of which 254 completed infant saliva collection at 3months. Of those, 132 had a 2nd trimester urine sample that could be used for the current analyses. Prior to data collection, participants provided informed consent to the procedures, which were approved by the University of Calgary Conjoint Health Research Ethics Board. 


\section{Procedures and measures Primary outcome}

Infant cortisol was assessed from whole saliva samples collected before (baseline) and after (5 min, $20 \mathrm{~min}$, and $40 \mathrm{~min}$ ) an infant stressor. The stressor was a blood draw completed by a certified pediatric phlebotomist when infants were 3 months of age. Saliva was collected using sorbettes (BD Visispear ${ }^{\mathrm{TM}}$ ), which have been validated for cortisol collection [16] and assayed for cortisol using the Salimetrics enzyme immunoassay. It has a lower limit of sensitivity of $0.007 \mu \mathrm{g} / \mathrm{dl}$, standard curve range from 0.012 to $3.0 \mu \mathrm{g} / \mathrm{dl}$, and average intra- and inter-assay coefficients of variation 3.5 and $5.1 \%$, respectively. Method accuracy, determined by serial dilution were 100.8 and $91.7 \%$. A random $10 \%$ of samples were assayed in duplicate to confirm reliability; the intra-assay coefficient of variation and the correlation coefficient between the duplicate tests were $c v=.035$ and $r=.99$, respectively. The mean values from duplicate samples were used for analysis.

\section{Primary exposure}

A spot urine sample was collected into sterile urine cups from pregnant women between 14 and 26 weeks of gestation. A complete description of the methods for detecting total BPA in the current samples was reported previously [21]. Briefly, urinary total BPA concentrations were quantified by online solid-phase extraction coupled to high performance liquid chromatography and an Orbitrap Elite hybrid mass spectrometer (Thermo Fisher Scientific, San Jose, CA). The recoveries of total BPA at two levels (1 ng/mL, $10 \mathrm{ng} / \mathrm{mL}$ ) were 88 and $102 \%$, with relative standard deviations (RSD) of $11 \%$. Linearity was evaluated over two orders of magnitude $(0.5 \mathrm{ng} / \mathrm{mL}$ to $50 \mathrm{ng} / \mathrm{mL}, 6$ point curve), and the regression coefficients of the standard curves were always $>0.99$. The limit of detection (LOD) was $0.32 \mathrm{ng} / \mathrm{mL}$. For statistical analyses, total BPA concentrations below the LOD were reported as the $\mathrm{LOD} / \sqrt{2}$.

\section{Other measures}

To correct for urinary dilution, urinary creatinine was quantified by laboratory services at the University of Alberta Hospital using a Synchron LX ${ }^{\bullet}$ System (Beckman Coulter). The limit of detection for creatinine was $10 \mathrm{mg} /$ $\mathrm{dL}$, with a dynamic range from 18 to $399 \mathrm{mg} / \mathrm{dL}$ $(r>0.99)$. Maternal sociodemographic information was collected via questionnaire during pregnancy, and infant birth outcomes were abstracted from the birth record. Prior to the blood draw, mothers were asked to verbally report on factors that could affect infant cortisol levels (i.e., sleep versus awake on the car ride to the laboratory, time since last feeding) and responses were recorded by a research assistant. Infant negative affect in the period from arrival at the laboratory until the blood draw was rated by a trained research assistant using the negative affect scale of the Behavior Rating Scales of the Bayley Scales of Infant Development 2nd edition [5], which assesses the amount and intensity of infant fussing/crying on a 5-point scale from "no negative affect displayed" to "three or more intense, heightened, or prolonged displays of negative affect".

\section{Statistical analysis}

Descriptive statistics are reported as geometric means and medians for continuous variables and percentages for categorical variables. Differences in demographic and study variables across maternal BPA tertile (Table 1) and infant sex (Table 2) were calculated by ANOVA or chi-squared, as appropriate. The hypotheses were tested using the MIXED procedure in SPSS version 22.0. Linear growth curve models were estimated to model the change in infant cortisol from baseline through $40 \mathrm{~min}$ post stressor (i.e., cortisol reactivity) as a function of maternal total BPA concentration during pregnancy. The outcome of these models was infant cortisol concentration, which was natural $\log$ transformed. At level 1, both the linear and quadratic effects of time were included to allow curvilinear trajectories in infant cortisol (cortisol increases are expected to slow or reverse between 20 and 40 min posts stressor) and to allow for individual differences in peak cortisol (maximum levels are delayed in some infants). Time was centered at baseline, thus the intercept in the growth curve models refers to infant cortisol concentration at baseline. Cortisol reactivity was determined by the slope parameter estimates for the linear and quadratic effects of time. The primary variables of interest were maternal total BPA concentration and the interaction term between maternal BPA and fetal sex; these were included in the level 2 submodel for the intercept and linear slope. Maternal total BPA concentration was centered at the sample mean and sex was centered at females. Because cortisol was natural log transformed, interpretation of the beta coefficients is facilitated by expressing each coefficient as a percent change using the formula $\beta \%$ change $=\left(e^{\beta}-1\right) \times 100$. The percent change can be thought of as an effect size because it refers to the size of the change in infant cortisol for each 1 unit change in the predictor (holding all other variables constant).

\section{Covariates}

Maternal urinary total BPA was adjusted for creatinine in statistical models in two ways to reflect current practice [4]: one was to add creatinine as an independent variable to the model (creatinine as covariate) and the other was to divide BPA by creatinine concentration (creatinine-corrected). Additional potential covariates that had been identified in previous studies [11, 23, 24] were considered 
Table 1 Participant characteristics and descriptive statistics by BPA tertile

\begin{tabular}{|c|c|c|c|c|c|c|c|c|c|}
\hline \multirow[b]{2}{*}{ Maternal Variable } & \multicolumn{3}{|c|}{ Lower tertile $(n=44)$} & \multicolumn{3}{|c|}{ Middle tertile $(n=44)$} & \multicolumn{3}{|c|}{ Upper tertile $(n=44)$} \\
\hline & GM(SE) & Median & Range & GM(SE) & Median & Range & GM(SE) & Median & Range \\
\hline Age (years) & $29.7(.61)$ & 30 & $24-40$ & $30.8(.56)$ & 31.5 & $20-39$ & $31.3(.63)$ & 32 & $22-42$ \\
\hline Pre-pregnancy BMI & $24.6(.65)$ & 24 & $19.8-42.3$ & $25.4(.82)$ & 25 & $18.4-38.5$ & $25.9(.93)$ & 24 & $19.1-43.1$ \\
\hline Total BPA (ng/mL) & $.34(.02)$ & .34 & $.16-.60$ & $.92(.04)$ & .93 & $.63-1.40$ & $3.84(1.58)$ & 3.15 & $1.43-43.42$ \\
\hline Creatinine (mmol/L) & $4.01(.44)$ & 4.10 & $.80-12.40$ & $8.06(.72)$ & 9.10 & $2.30-19.10$ & $11.96(.94)$ & 13.10 & $3.90-32.80$ \\
\hline \multicolumn{10}{|l|}{ Infant Variable } \\
\hline $\begin{array}{l}\text { Gestational age at birth } \\
\text { (weeks) }\end{array}$ & $39.5(.19)$ & 40.0 & $35.3-41.6$ & $39.0(.27)$ & 39.2 & $33.0-41.3$ & $39.2(.21)$ & 39.0 & $35.6-41.7$ \\
\hline Birthweight (grams) & $3501(74)$ & 3418 & $2725-4904$ & $3254(86)$ & 3410 & $2030-4420$ & $3329(75)$ & 3385 & $2220-4200$ \\
\hline \multirow[t]{2}{*}{ Baseline cortisol ( $\mu \mathrm{g} / \mathrm{dL})$} & $.25(.03)$ & .26 & $.05-1.02$ & $.25(.04)$ & .26 & $.06-1.51$ & $.22(.04)$ & .22 & $.10-1.17$ \\
\hline & Percent & & & Percent & & & Percent & & \\
\hline \multicolumn{10}{|l|}{ Household Income } \\
\hline$<\$ 20,000$ & 0 & & & 4.5 & & & 0 & & \\
\hline$\$ 20 k-\$ 40 k$ & 2.4 & & & 2.3 & & & 9.1 & & \\
\hline$\$ 40 k-\$ 70 k$ & 11.9 & & & 11.4 & & & 11.4 & & \\
\hline$\$ 70 k-\$ 100 k$ & 28.6 & & & 22.7 & & & 25.0 & & \\
\hline$>\$ 100,000$ & 57.1 & & & 59.1 & & & 54.5 & & \\
\hline \multicolumn{10}{|l|}{ Education } \\
\hline High school diploma & 14.3 & & & 6.8 & & & 4.5 & & \\
\hline College diploma & 11.9 & & & 15.9 & & & 34.1 & & \\
\hline University degree & 73.8 & & & 77.3 & & & 61.4 & & \\
\hline \multicolumn{10}{|l|}{ Ethnicity } \\
\hline White & 86.4 & & & 77.3 & & & 86.4 & & \\
\hline Other & 13.6 & & & 22.7 & & & 13.6 & & \\
\hline \multicolumn{10}{|l|}{ Marital status } \\
\hline Married & 90.7 & & & 81.8 & & & 90.9 & & \\
\hline Common law & 9.3 & & & 15.9 & & & 9.1 & & \\
\hline $\begin{array}{l}\text { Single/separated/ } \\
\text { divorced }\end{array}$ & 0 & & & 2.3 & & & 0 & & \\
\hline Nulliparous & 52.3 & & & 47.7 & & & 61.4 & & \\
\hline \multicolumn{10}{|l|}{ Infant Sex } \\
\hline Male & 50 & & & 50 & & & 50 & & \\
\hline
\end{tabular}

Note. GM geometric mean, SE standard error of the mean

as potential confounders of the maternal BPA - infant cortisol association. Selection of covariates, random effects and error structure was based upon model fit as assessed by -2 log likelihood and Bayesian Information Criterion (BIC), except for infant gestational age at birth which was included because it is associated with infant HPA axis function. In preliminary models, infant age at assessment, infant birthweight, infant sleeping versus awake on the car ride to the appointment, infant behavioral fussiness at baseline, time of day at baseline, maternal or infant medication use, and maternal pre-pregnancy BMI did not improve model fit and were therefore excluded from further analysis. Covariates that were retained included gestational week of pregnancy for maternal urinary BPA collection, time of day at which maternal urine was collected, and infant gestational age at birth.

\section{Sensitivity analyses}

Because gestational age at birth and birthweight are associated with infant HPA axis function $[11,23]$ and prenatal BPA exposure $[6,52]$, we conducted sensitivity analyses excluding infants with low birthweight $(<2500 \mathrm{~g})$ or preterm birth $(<37$ weeks gestation). To determine the extent to which urinary dilution may affect the association between BPA and cortisol, all analyses were re-run excluding women who had urinary creatinine concentrations that were 
Table 2 Participant characteristics and descriptive statistics by child sex

\begin{tabular}{|c|c|c|c|c|c|c|}
\hline \multirow[b]{2}{*}{ Maternal Variable } & \multicolumn{3}{|c|}{ Males $(n=66)$} & \multicolumn{3}{|c|}{ Females $(n=66)$} \\
\hline & GM(SE) & Median & Range & GM(SE) & Median & Range \\
\hline Age (years) & $31.1(.47)$ & 31 & $24-40$ & $30.1(.50)$ & 31 & $20-42$ \\
\hline Pre-pregnancy BMI & $24.8(.65)$ & 24 & $18.4-42.2$ & $25.8(.67)$ & 25 & $19.1-43.1$ \\
\hline Total BPA (ng/mL) & $1.10(.97)$ & .89 & $.16-43.42$ & $1.04(.63)$ & .98 & $.23-39.84$ \\
\hline Creatinine (mmol/L) & $6.74(.73)$ & 7.65 & $.80-32.80$ & $7.87(.74)$ & 8.20 & $.90-24.70$ \\
\hline \multicolumn{7}{|l|}{ Infant Variable } \\
\hline Gestational age at birth (weeks) & $39.2(.19)$ & 39.3 & $33.0-41.7$ & $39.3(.17)$ & 39.9 & $35.3-41.4$ \\
\hline Birthweight (grams) & $3448(72)$ & 3510 & $2030-4904$ & $3273(54)$ & 3352 & $2215-4200$ \\
\hline \multirow[t]{2}{*}{ Baseline cortisol ( $\mu \mathrm{g} / \mathrm{dL})$} & $.25(.02)$ & .24 & $.05-1.03$ & $.24(.03)$ & .23 & $.06-1.51$ \\
\hline & Percent & & & Percent & & \\
\hline \multicolumn{7}{|l|}{ Household Income } \\
\hline$<\$ 20,000$ & 1.6 & & & 1.5 & & \\
\hline$\$ 20 k-\$ 40 k$ & 6.3 & & & 3.0 & & \\
\hline$\$ 40 k-\$ 70 k$ & 4.7 & & & 18.2 & & \\
\hline$\$ 70 k-\$ 100 k$ & 23.4 & & & 27.3 & & \\
\hline$>\$ 100,000$ & 64.1 & & & 50.0 & & \\
\hline \multicolumn{7}{|l|}{ Education } \\
\hline High school diploma & 6.3 & & & 10.6 & & \\
\hline College diploma & 14.1 & & & 27.3 & & \\
\hline University degree & 79.8 & & & 62.1 & & \\
\hline \multicolumn{7}{|l|}{ Ethnicity } \\
\hline White & 80.3 & & & 86.4 & & \\
\hline Other & 19.7 & & & 13.6 & & \\
\hline \multicolumn{7}{|l|}{ Marital status } \\
\hline Married & 92.3 & & & 83.3 & & \\
\hline Common law & 7.7 & & & 15.2 & & \\
\hline Single/separated/divorced & 0 & & & 1.5 & & \\
\hline Nulliparous & 53.0 & & & 54.5 & & \\
\hline
\end{tabular}

Note. GM geometric mean. SE standard error of the mean

considered too diluted $(<2.65 \mathrm{mmol}$ creatinine/L) or too concentrated ( $>26.5 \mathrm{mmol}$ creatinine/L) according to the World Health Organization guidelines for occupational monitoring, which have also been applied to nonoccupational studies [4].

\section{Results}

\section{Descriptive findings}

Overall, the participants were relatively well-educated $(71 \%$ had a university education), married or living in commonlaw relationships $(99 \%)$, mature (mean age $=30.6$ years, range $20-42$ years) and nulliparous (54\%) at enrollment. The majority of women (82\%) lived in households with annual income greater than $\$ 70,000 \mathrm{CAD}$ (according to Statistics Canada, the median household income within the recruitment region was $\$ 98,030$ ), and most self-identified as White (83\%). Infants averaged 12.5 weeks old at time of assessment (range 9.1 - 16 weeks). The sex ratio of infants was equal (66 m: 66f).

As the sample was embedded within a larger cohort study, we tested for potential selection bias by comparing the characteristics of women included in this study with the full APrON cohort. Women in the current analysis had higher pre-pregnancy BMI compared to the full cohort $\left(25.7 \mathrm{~kg} / \mathrm{m}^{2}\right.$ versus $\left.24.1 \mathrm{~kg} / \mathrm{m}^{2} ; p<.05\right)$, but did not differ from the full cohort on income, ethnicity, age, parity, or marital status (all $p$ values $>.05$ ).

Characteristics of the participants by BPA tertile are listed in Table 1 and by sex in Table 2. Table 1 reveals that creatinine concentrations increased by BPA tertile, $F(2,129)=34.5, p<.001$. All other variables did not differ between groups $(p>0.05)$. Table 2 shows that, as expected, female infants had lower birthweight compared to male infants, $F(2130)=4.7$, 
$p=.03$. All other variables did not differ between groups.

Total BPA was detected above the LOD in $90.9 \%$ of the maternal urine samples. Average BPA concentrations $(\mathrm{GM}=1.07 \mathrm{ng} / \mathrm{mL}$, range $.16-43.4 \mathrm{ng} / \mathrm{mL})$ were within the range previously reported for pregnant women in North America. Creatinine was detected in all samples. Cortisol was detected in all samples, however, two samples yielded results that were not biologically plausible $(>3 \mu \mathrm{g} / \mathrm{dL})[25,35,50]$, and were removed.

\section{Associations between maternal total BPA and infant baseline cortisol}

The association between maternal total BPA concentration and infant cortisol was not significant for baseline, $\beta=0.002$ (95\% CI: $-0.08,0.08)$, when infant sex was not considered in the model (see Model 1, Table 3). However, when sex of the infant, and the interaction term between sex and total BPA concentration, were added to the model, significant conditional associations were observed (see Model 2, Table 3). Specifically, higher maternal total BPA was associated with a significant increase in baseline salivary cortisol among female infants, $\beta=0.13$ (95\% CI: $0.01,0.26$ ), corresponding to a $14 \%$ increase per one unit increase in maternal total BPA (note that total BPA was $\log 10$ transformed therefore 1 unit $=$ a 10-fold increase). The association between maternal total BPA and baseline infant cortisol was significantly different for male and female infants, $\beta=-0.22$ (95\% CI: $-0.39,-0.05)$. In contrast to the increase in baseline cortisol observed in female infants, each 10-fold increase in maternal total BPA was associated with an $8.1 \%$ decrease in baseline cortisol for male infants.

\section{Associations between maternal total BPA and infant cortisol reactivity}

There was no association between maternal total BPA concentration and infant cortisol reactivity (i.e., Time), $\beta=0.02$ (95\% CI: $-0.11,0.15)$ when infant sex was not considered in the model (see Model 1, Table 3). With sex added to the model, the association between maternal total BPA and infant cortisol reactivity was non-significant for female infants, $\beta=-0.15$ (95\% CI: $-0.35,0.05$ ), however the association differed for male and females infants, $\beta=.30$, (95\% CI: 0.04, 0.56), indicating that the association between maternal BPA and infant cortisol reactivity was dependant on infant sex. For female infants, each 10-fold increase in maternal BPA was associated with a $14 \%$ reduction in cortisol reactivity, whereas the same increase was associated with a $17 \%$ increase in cortisol reactivity among male infants. To illustrate these associations, the estimates obtained in Model 2 have been plotted (Fig. 1) at the mean of the upper and lower quartiles for BPA to represent the highest and lowest exposures in the sample.

Results after adjusting for creatinine (see Model 3, Table 3) were similar to those reported in Model 2. However, the association between maternal BPA and cortisol at baseline for females was reduced to a nonsignificant effect, $\beta=0.13$ (95\% CI: $-0.01,0.28$ ), and the associations between BPA and reactivity and sex differences in the associations between BPA and reactivity become slightly larger. One additional model (results not shown) with BPA corrected for creatinine revealed comparable, although slightly smaller, effect estimates relative to those observed in Models 2 and 3, and the standard errors in this model were slightly larger. All confidence intervals for effect estimates spanned zero in this model.

\section{Sensitivity analysis}

To determine whether infants who were born preterm (<37 weeks gestation) or low birthweight $(<2500 \mathrm{~g})$ may be contributing to our findings, the analyses were redone with nine infants excluded. The findings reported in Table 3 remain unchanged after these exclusions (data not shown). To determine whether urinary dilution/concentration may have affected the results, we excluded women with low $(n=14)$ or high $(n=1)$ creatinine concentrations (using the WHO criteria defined above). Again, the findings reported in Table 3 remain unchanged after these exclusions (data not shown).

\section{Discussion}

To our knowledge, these data are the first to demonstrate an association between maternal urinary total BPA concentrations during pregnancy and offspring HPA axis function in a human population. The data indicated that associations between prenatal maternal BPA and infant cortisol were dependent on sex. For females, elevated maternal BPA was associated with elevated baseline cortisol, whereas in males it was associated with decreased baseline cortisol. Furthermore, greater maternal urinary total BPA concentration was associated with attenuation of infant cortisol reactivity in female infants but potentiation of cortisol reactivity in male infants. These findings suggest that fetal/infant sex plays a critical role in the association between maternal BPA concentration and children's HPA axis function.

The sex differences observed in these data recapitulate findings in rodent models. Female, but not male, rodents had increased basal corticosterone levels following perinatal BPA exposure but males had exaggerated corticosterone reactivity to a stressor $[40,42]$. Although exaggerated corticosterone reactivity was also observed in females, the effect in males was significantly larger than the effect in females. The consistency of the human data with animal evidence 
Table 3 Model estimates for the association between maternal total urinary BPA (log10 ng/mL) concentration and infant salivary cortisol concentration (natural log $\mu \mathrm{g} / \mathrm{dL}$ ): $n=132$

\begin{tabular}{|c|c|c|c|c|c|c|}
\hline \multirow[b]{2}{*}{ Fixed Effects } & \multicolumn{2}{|l|}{ Model 1: BPA } & \multicolumn{2}{|c|}{ Model 2: BPA with sex } & \multicolumn{2}{|c|}{ Model 3: BPA with sex and creatinine } \\
\hline & $\begin{array}{l}\beta \text { Coefficient } \\
(95 \% \mathrm{Cl})\end{array}$ & $\begin{array}{l}\text { \% change } \\
(95 \% \mathrm{Cl})\end{array}$ & $\begin{array}{l}\beta \text { Coefficient } \\
(95 \% \mathrm{Cl})\end{array}$ & \% change ( $95 \% \mathrm{Cl})$ & $\begin{array}{l}\beta \text { Coefficient } \\
(95 \% \mathrm{Cl})\end{array}$ & $\%$ change $(95 \% \mathrm{Cl})$ \\
\hline $\begin{array}{l}\text { INTERCEPT } \\
\text { (baseline } \\
\text { cortisol) }\end{array}$ & $\begin{array}{l}.31 \\
(.12, .49)\end{array}$ & $\begin{array}{l}\mathrm{GM}=.37 \mu \mathrm{g} / \\
\mathrm{dL} \text { at baseline }\end{array}$ & $\begin{array}{l}.31 \\
(.12, .50)\end{array}$ & $\begin{array}{l}\mathrm{GM}=.38 \mu \mathrm{g} / \mathrm{dL} \text { at } \\
\text { baseline for females }\end{array}$ & $\begin{array}{l}.31 \\
(.12, .50)\end{array}$ & $\mathrm{GM}=.38 \mu \mathrm{g} / \mathrm{dL}$ at baseline for females \\
\hline $\begin{array}{l}\text { Time of day } \\
\text { for urine } \\
\text { collection } \\
\text { (hours) }\end{array}$ & $\begin{array}{l}.001 \\
(-.006, .008)\end{array}$ & & $\begin{array}{l}.002 \\
(-.005, .009)\end{array}$ & & $\begin{array}{l}.002 \\
(-.005, .009)\end{array}$ & \\
\hline $\begin{array}{l}\text { Gestational } \\
\text { age at urine } \\
\text { collection } \\
\text { (weeks) }\end{array}$ & $\begin{array}{l}-.004 \\
(-.01, .003)\end{array}$ & & $\begin{array}{l}-.005 \\
(-.01, .003)\end{array}$ & & $\begin{array}{l}-.005 \\
(-.01, .003)\end{array}$ & \\
\hline $\begin{array}{l}\text { Gestational } \\
\text { age at birth } \\
\text { (weeks) }\end{array}$ & $\begin{array}{l}-.005 \\
(-.02, .01)\end{array}$ & & $\begin{array}{l}-.006 \\
(-.02, .01)\end{array}$ & & $\begin{array}{l}-.005 \\
(-.02, .01)\end{array}$ & \\
\hline $\begin{array}{l}\text { Creatinine } \\
(\mathrm{mmol} / \mathrm{L})\end{array}$ & & & & & $\begin{array}{l}.0001 \\
(-.005, .005)\end{array}$ & \\
\hline Infant Sex & & & $\begin{array}{l}-.02 \\
(-.07, .03)\end{array}$ & & $\begin{array}{l}-.02 \\
(-.07, .03)\end{array}$ & \\
\hline $\begin{array}{l}\text { BPA } \\
(\log 10 \mathrm{ng} / \mathrm{mL})\end{array}$ & $\begin{array}{l}.002 \\
(-.08, .08)\end{array}$ & $\begin{array}{l}.2 \%(-.8,8) \\
\text { increase } \\
\text { per } 10 \text {-fold } \\
\text { increase } \\
\text { in BPA at } \\
\text { baseline }\end{array}$ & $\begin{array}{l}.13 \\
(.01, .26)\end{array}$ & $\begin{array}{l}14 \%(.7,30) \text { increase per } \\
10 \text {-fold increase in BPA at } \\
\text { baseline for females }\end{array}$ & $\begin{array}{l}.13 \\
(-.01, .28)\end{array}$ & $\begin{array}{l}14 \%(-1,32) \text { increase per } 10-\text { fold increase } \\
\text { in BPA at baseline for females }\end{array}$ \\
\hline BPA $X$ sex & & & $\begin{array}{l}-.22 \\
(-.39,-.05)\end{array}$ & $\begin{array}{l}-20 \%(-32,-5) \text { difference } \\
\text { between males and females; } \\
\text { net effect is } 8.1 \% \text { decrease } \\
\text { per } 10 \text {-fold increase in BPA } \\
\text { at baseline for males }\end{array}$ & $\begin{array}{l}-.22 \\
(-.39,-.05)\end{array}$ & $\begin{array}{l}-20 \%(-32,-5) \text { difference between males } \\
\text { and females; net effect is a } 9 \% \text { decrease } \\
\text { per } 10 \text {-fold increase in BPA at baseline for } \\
\text { males }\end{array}$ \\
\hline TIME $^{2}$ (hours) & $\begin{array}{l}-.33 \\
(-.47,-.18)\end{array}$ & & $\begin{array}{l}-.33 \\
(-.48,-.18)\end{array}$ & & $\begin{array}{l}-.33 \\
(-.48,-.18)\end{array}$ & \\
\hline TIME (hours) & $\begin{array}{l}.31 \\
(.19, .44)\end{array}$ & $\begin{array}{l}37 \%(21,55) \\
\text { increase } \\
\text { per hour }\end{array}$ & $\begin{array}{l}.32 \\
(.19, .46)\end{array}$ & $\begin{array}{l}38 \%(21,58) \text { increase per } \\
\text { hour for females }\end{array}$ & $\begin{array}{l}.32 \\
(.19, .45)\end{array}$ & $38 \%(21,57)$ per hour for females \\
\hline $\begin{array}{l}\text { Gestational } \\
\text { age at birth } \\
\text { (weeks) }\end{array}$ & $\begin{array}{l}-.02 \\
(-.04, .01)\end{array}$ & & $\begin{array}{l}-.02 \\
(-.04, .01)\end{array}$ & & $\begin{array}{l}-.02 \\
(-.04, .01)\end{array}$ & \\
\hline $\begin{array}{l}\text { Creatinine } \\
(\mathrm{mmol} / \mathrm{L})\end{array}$ & & & & & $\begin{array}{l}.003 \\
(-.005, .01)\end{array}$ & \\
\hline Infant Sex & & & $\begin{array}{l}-.03 \\
(-.11, .05)\end{array}$ & $\begin{array}{l}-3 \%(-10,5) \text { difference } \\
\text { between males and females; } \\
\text { net effect is } 34 \% \text { increase } \\
\text { per hour in males }\end{array}$ & $\begin{array}{l}-.02 \\
(-.11, .06)\end{array}$ & $\begin{array}{l}-3 \%(-10,5) \text { difference between males } \\
\text { and females; net effect is } 34 \% \text { increase } \\
\text { per hour in males }\end{array}$ \\
\hline $\begin{array}{l}\text { BPA } \\
(\log 10 \mathrm{ng} / \mathrm{mL})\end{array}$ & $\begin{array}{l}.02 \\
(-.11, .15)\end{array}$ & $\begin{array}{l}2 \%(-10,17) \\
\text { per hour per } \\
10 \text {-fold } \\
\text { increase in } \\
\text { BPA }\end{array}$ & $\begin{array}{l}-.15 \\
(-.35, .05)\end{array}$ & $\begin{array}{l}-14 \%(-30,5) \text { decrease per } \\
\text { hour for females per } 10 \text {-fold } \\
\text { increase in BPA }\end{array}$ & $\begin{array}{l}-.20 \\
(-.43, .03)\end{array}$ & $\begin{array}{l}-18 \%(-35,3) \text { decrease per hour for } \\
\text { females per } 10 \text {-fold increase in BPA }\end{array}$ \\
\hline BPA $X$ sex & & & $\begin{array}{l}.30 \\
(.04, .56)\end{array}$ & $\begin{array}{l}35 \%(4,75) \text { difference } \\
\text { between males and } \\
\text { females; net effect is } \\
\text { a } 17 \% \text { per hour increase } \\
\text { in males per } 10 \text {-fold } \\
\text { increase in BPA }\end{array}$ & $\begin{array}{l}.33 \\
(.06, .60)\end{array}$ & $\begin{array}{l}39 \%(6,82) \text { difference between males and } \\
\text { females; net effect is a } 15 \% \text { per hour } \\
\text { increase in males per } 10 \text {-fold increase in } \\
\text { BPA }\end{array}$ \\
\hline
\end{tabular}




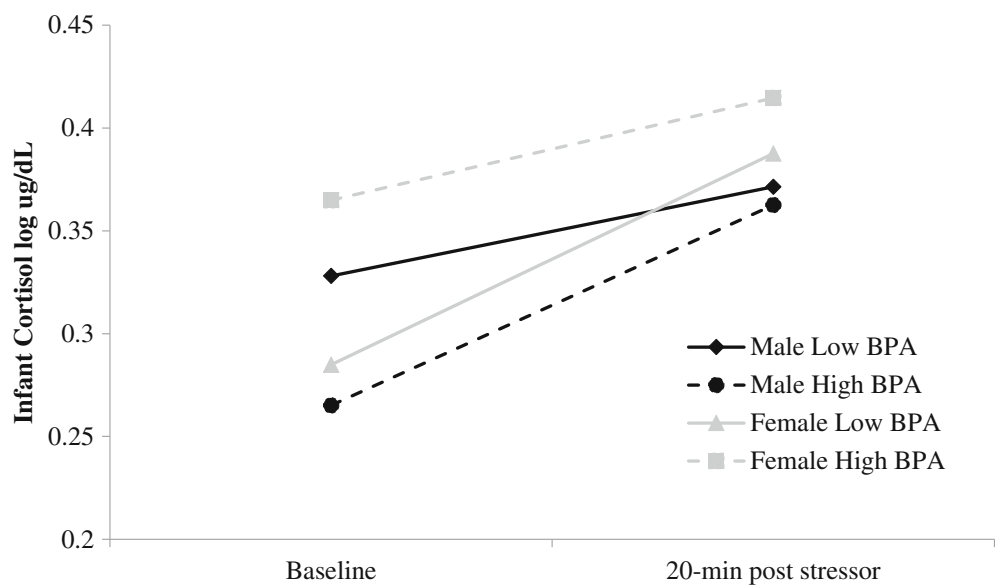

Fig. 1 Infant baseline cortisol and cortisol reactivity as a function of maternal urinary total BPA concentration and infant sex

supports the biological plausibility of these findings. Note however that not all animal studies have been consistent Chen and colleagues observed elevations in basal and reactivity corticosterone measure only in males. Differences between studies could be related to factors such as dose and age of testing.

It is important to note that the sex differences we observed cannot be accounted for by pre-existing sex differences in baseline cortisol or cortisol reactivity. When we removed BPA from the statistical model, there were no sex difference in baseline cortisol, $\beta=-.01$ (95\% CI: -0.06 , 0.04 ), or in cortisol reactivity, $\beta=-.03$ (95\% CI: -0.11 , 0.05). Sex differences in baseline cortisol and cortisol reactivity became apparent only as a function of prenatal BPA exposure.

Recently, Chen and colleagues [13] reported that BPArelated changes in the offspring HPA axis in rats were responsible for increases in anxiety/depression-like behaviours, possibly through epigenetic changes in the hypothalamus and hippocampus [30]. It is well accepted that alteration of HPA axis function as a consequence of prenatal and early life exposure is a primary mechanism by which such exposures have long-lasting effects on behavior and development. Our findings are consistent with the hypothesis that BPA-related behavioral changes observed in human children may be accompanied by changes in the infant HPA axis. This hypothesis is supported both by the well-established role of the HPA axis in developmental psychopathology [34] and the frequently observed sex differences in behavioral outcomes of children prenatally exposed to BPA [9, 20, 27, 41,44].

Although previous studies have not examined HPA axis function in human offspring as a function of prenatal BPA exposure, several studies have examined behavioral outcomes. These studies have consistently reported sex differences, however the direction of these sex differences was not consistent across studies. Some studies suggest that perinatal BPA exposure is associated with increased internalizing and externalizing behaviors in females $[8,9]$, whereas others report increases in these behaviors among males [20, 27, 41, 44]. Such inconsistencies across studies may be related to the timing of exposure, as suggested by the findings of Roen and colleagues, who reported contrasting findings for prenatal versus postnatal BPA exposure. Prenatal exposure was associated with increased behavioural problems in boys but not girls whereas postnatal exposure was associated with increased behavioural problems in girls but not boys. Further research is needed to clarify the pattern of sex differences in the associations between BPA exposure and behavioral outcomes in children, and to determine what role the HPA axis function may play in these outcomes.

Although the mechanisms by which prenatal BPA exposure alters HPA axis function are not conclusively known, several potential routes have been identified. First, BPA, like other agonists (i.e., dexamethasone and cortisol) can bind to glucocorticoid receptors [43], making plausible direct stimulation of the HPA axis through BPA binding to glucocorticoid receptors. Second, BPA may disrupt the effects of sex hormones on the development and function of the HPA axis. Sex differences in HPA axis function appear to be modulated by the gonadal steroid environment, acting in part by modulating adrenal, anterior pituitary, and hypothalamic functions [26]. Given that BPA is an estrogenic endocrine disruptor [58] and that estrogen plays a critical role in HPA axis regulation [55], it is plausible that changes in estrogen receptors following BPA exposure influence HPA axis development and function. The involvement of gonadal steroids may also help to explain sex differences in the effects of BPA on behavioural outcomes. Third, BPA may alter placental metabolism of endogenous maternal cortisol by increasing the expression of $11 \beta$ hydroxysteroid dehydrogenasetype 1 (11ß-HSD1) [54], 
an enzyme that preferentially converts the inactive hormone cortisone to the active hormone cortisol [7, 22, 56]. This change of placental metabolism would potentially increase fetal exposure to maternal cortisol, and thereby alter infant HPA axis function and potentially, child behaviour. Further research that assesses prenatal BPA exposure, infant HPA axis function, and child behaviour is needed to elaborate the potential pathways by which BPA exposure can influence child behaviour.

It is important to note that the exposures observed in the current sample are well below the exposures that animals receive in laboratory studies, even in so-called low dose studies, and below the Tolerable Daily Intakes (TDIs) established by Canadian health authorities. BPA exposure in the Canadian population is likely well below the provisional TDIs established by the Food Directorate of Health Canada (25 $\mu \mathrm{g} / \mathrm{kg}$ bw/day) $[19,28]$. Based on data from Covaci and colleagues [15], where daily intake was calculated from BPA concentrations in spot urine samples of mothers, we estimate that the highest daily intake in the current sample ranges from 0.9 $1.1 \mu \mathrm{g} / \mathrm{kg}$ bw/day. The fact that associations with infant HPA axis function can be detected even at exposure levels well below the most stringent (European) TDIs suggests that such exposures may play a role in shaping the development of the infant HPA axis.

The clinical significance of these findings is not clear given the lack of normative data on cortisol reactivity in young infants. Nevertheless, it may be possible to evaluate the clinical significance of these findings by comparison to data on dampening of the cortisol response using sucrose following inoculations [36] or lidocaine prior to circumcision [48], both of which result in an approximately $30 \%$ reduction in cortisol relative to baseline or control, respectively. Note however that there are few studies and not all have observed significant effects, and while sucrose is now recommended for infant inoculations [46], the most convincing evidence comes from behavioural rather than physiologic data. The current study observed an approximately $37 \%$ increase in cortisol per hour as a function of each 10-fold increase in prenatal BPA exposure, and there was an 11.3-fold higher BPA concentration in the upper compared to the lower tertile (see Table 1). Given that cortisol tends to peak at about $30 \mathrm{~min}$ post-stressor, these data suggest that infants in the upper tertile of BPA exposure had 20\% larger increases in cortisol over the first $30 \mathrm{~min}$ following the blood draw compared to infants in the lower tertile of exposure. Further study is required to determine whether BPA-related increases in cortisol are associated with clinically relevant behavioral or health outcomes.

\section{Strengths and limitations}

This study had several strengths and limitations. To our knowledge, it is the first human study to examine the association between maternal urinary total BPA and HPA axis function in children. With respect to limitations, the sample size was modest and it will be important to replicate these findings in a larger study to confirm these associations. Although sample size was not a concern for those effects that were significant, it will be important to replicate these findings in a larger sample to confirm these associations. Second, we used a single measure of maternal urinary BPA in mid-pregnancy as our exposure variable. BPA has relatively short half-life following oral exposure $[49,53]$ and there is inherent variability in BPA concentrations over time, which pregnancy may accentuate [9]. Accordingly, a single spot urine sample may not provide a complete estimate of fetal in utero exposure to BPA. Nevertheless, to reduce measurement variability associated with a single sample, we included in our statistical models the gestational week and the time day at which the urine sample was collected, as suggested by Braun and colleagues [9]. Further, any potential measurement bias resulting from a single urine sample would likely be non-differential, as the measurement error applies equally to both lower and higher BPA concentrations, and any measurement bias would likely decrease the association between BPA urinary concentrations and infant cortisol. Thus, the effects observed here are more likely to underestimate rather than overestimate the true association between maternal BPA and offspring cortisol. Third, although we tested many potential covariates and included those that were theoretically important and statistically related to the outcome in our models, the existence of residual confounding in our findings cannot be disregarded. Finally, considering that the APrON study population is largely White, more highly educated, and has higher income compared to the Canadian population [29], generalization to other ethnic and socioeconomic groups should be made with caution. Nevertheless, we expect on the basis of our sample that these findings apply to the majority of middle class women and infants living in the developed world.

\section{Conclusion}

Our results suggest that prenatal exposure to BPA is associated with sex-specific changes in infant HPA axis function. Given that HPA axis dysfunction is a presumed mechanism underlying developmental psychopathology and behavioral problems in children, we propose that sexually dimorphic associations between prenatal BPA exposure and behavioral outcomes in children are 
mediated, at least in part, by sex-specific dysregulation of the HPA axis.

\section{Abbreviations}

APrON: Alberta Pregnancy Outcomes and Nutrition; BIC: Bayesian Information Criterion; BPA: bisphenol A; HPA: hypothalamic-pituitary-adrenal

\section{Acknowledgments}

The authors gratefully acknowledge the participants of the APrON study and the members of the APrON study team whose individual members are B.J. Kaplan, C.J. Field, D. Dewey, R.C. Bell, F.P. Bernier, M. Cantell, L.M. Casey, M. Eliasziw, A. Farmer, L. Gagnon, G.F. Giesbrecht, L. Goonewardene, D.W. Johnston, L. Kooistra, N. Letourneau, D.P. Manca, J.W. Martin, L.J. McCargar, M. O'Beirne, V.J. Pop, and N. Singhal.

\section{Funding}

This research was supported by operating grants from the Canadian Institutes of Health Research (grants MOP-106593 and MOP-123535), Alberta InnovatesHealth Solutions (AIHS), and the Alberta Centre for Centre for Child, Family and Community Research (grant 100415TOP). ME and JT were supported by graduate studentship awards from the Alberta Children's Hospital Research Institute and Queen Elizabeth II Graduate (Doctoral) Scholarships for 2015-2016. $J L$ was supported by a studentship from AlHS. GFG was supported by a salary award from the Canadian Child Health Clinician Scientist Program. These funding agencies had no role in the design or conduct of the study, in the collection, analysis and interpretation of the data, or in the preparation, review or approval of the manuscript.

\section{Availability of data and materials}

The dataset analysed during the current study are not publically available because consent was not obtained from participants to do so.

\section{Authors' contributions}

All authors contributed to the conceptualization of this study, contributed to revising the manuscript, and approved the final manuscript. GFG conducted the data analyses; $J$ performed the laboratory analysis of BPA; GFG, ME, and $\mathrm{JT}$ composed the first draft of the manuscript.

\section{Competing interests}

The authors declare that they have no competing interests.

\section{Consent for publication}

Not applicable.

\section{Ethics approval and consent to participate}

This study was approved by the University of Calgary Conjoint Health Research Ethics Board (ID 22101). All participants provided written informed consent prior to data collection.

\section{Publisher's Note}

Springer Nature remains neutral with regard to jurisdictional claims in published maps and institutional affiliations.

\section{Author details}

'Department of Paediatrics, University of Calgary, 2500 University Drive, Calgary, AB T2N 1N4, Canada. ${ }^{2}$ Department of Community Health Sciences, University of Calgary, Calgary, AB, Canada. ${ }^{3}$ Department of Laboratory Medicine and Pathology, University of Alberta, Edmonton, $A B$, Canada. ${ }^{4}$ Department of Psychology, University of Calgary, Calgary, AB, Canada. ${ }^{5}$ Faculty of Nursing, University of Calgary, Calgary, AB, Canada.

\section{Received: 14 December 2016 Accepted: 11 May 2017}

\section{Published online: 19 May 2017}

\section{References}

1. Arbuckle TE, Davis K, Marro L, Fisher M, Legrand M, LeBlanc A, et al. Phthalate and bisphenol a exposure among pregnant women in canada-results from the mirec study. Environ Int. 2014;68:55-65.

2. Bailin PS, Byrne M, Lewis S, Liroff R. 2008. Public awareness drives market for safer alternatives: Bisphenol a market analysis report.
3. Balakrishnan B, Henare K, Thorstensen EB, Ponnampalam AP, Mitchell MD. Transfer of bisphenol a across the human placenta. Am J Obstet Gynecol. 2010;202:393. e391-397

4. Barr DB, Wilder LC, Caudill SP, Gonzalez AJ, Needham LL, Pirkle JL. Urinary creatinine concentrations in the U.S. population: implications for urinary biologic monitoring measurements. Environ Health Perspect. 2005;113:192-200.

5. Bayley N. Bayley scales of infant development. 2nd ed. San Antonio: Psycholgical Corporation; 1993.

6. Behnia F, Peltier M, Getahun D, Watson C, Saade G, Menon R. High bisphenol a (bpa) concentration in the maternal, but not fetal, compartment increases the risk of spontaneous preterm delivery. J Matern Fetal Neonatal Med. 2016;29:3583-9.

7. Benediktsson R, Calder AA, Edwards CR, Seckl JR. Placental 11 betahydroxysteroid dehydrogenase: a key regulator of fetal glucocorticoid exposure. Clin Endocrinol. 1997:46:161-6.

8. Braun JM, Yolton K, Dietrich KN, Hornung R, Ye X, Calafat AM, et al. Prenatal bisphenol a exposure and early childhood behavior. Environ Health Perspect. 2009;1 17:1945-52.

9. Braun JM, Kalkbrenner AE, Calafat AM, Bernert JT, Ye X, Silva MJ, et al. Variability and predictors of urinary bisphenol a concentrations during pregnancy. Environ Health Perspect. 2011;119:131-7.

10. Braun JM, Smith KW, Williams PL, Calafat AM, Berry K, Ehrlich S, et al. Variability of urinary phthalate metabolite and bisphenol a concentrations before and during pregnancy. Environ Health Perspect. 2012;120:739-45.

11. Buss C, Entringer S, Davis EP, Hobel CJ, Swanson JM, Wadhwa PD, et al. Impaired executive function mediates the association between maternal pre-pregnancy body mass index and child adhd symptoms. PLoS One. 2012;: 237758.

12. Chapin RE, Adams J, Boekelheide K, Gray LE Jr, Hayward SW, Lees PS, et al. Ntp-cerhr expert panel report on the reproductive and developmental toxicity of bisphenol a. Birth Defects Res B Dev Reprod Toxicol. 2008:83:157-395.

13. Chen F, Zhou L, Bai Y, Zhou R, Chen L. Hypothalamic-pituitary-adrenal axis hyperactivity accounts for anxiety- and depression-like behaviors in rats perinatally exposed to bisphenol a. J Biomed Res. 2015;29:250-8.

14. Chevrier J, Gunier RB, Bradman A, Holland NT, Calafat AM, Eskenazi B, et al. Maternal urinary bisphenol a during pregnancy and maternal and neonatal thyroid function in the chamacos study. Environ Health Perspect. 2013;121:138-44.

15. Covaci A, Den Hond E, Geens T, Govarts E, Koppen G, Frederiksen H, et al. Urinary bpa measurements in children and mothers from six european member states: overall results and determinants of exposure. Environ Res. 2015;141:77-85.

16. de Weerth C, Jansen J, Vos MH, Maitimu I, Lentjes EG. A new device for collecting saliva for cortisol determination. Psychoneuroendocrinology. 2007;32:1144-8.

17. Del Giudice M, Ellis BJ, Shirtcliff EA. The adaptive calibration model of stress responsivity. Neurosci Biobehav Rev. 2011;35:1562-92.

18. Ejaredar M, Lee Y, Roberts DJ, Sauve R, Dewey D. Bisphenol a exposure and children's behavior: A systematic review. J Expo Sci Environ Epidemiol. 2017; 27:175-83.

19. European Food Safety Authority. 2015. Bisphenol a. Available: http://www. efsa.europa.eu/en/topics/topic/bisphenol.htm [Accessed 21 Mar 2017.

20. Evans SF, Kobrosly RW, Barrett ES, Thurston SW, Calafat AM, Weiss B, et al. Prenatal bisphenol a exposure and maternally reported behavior in boys and girls. Neurotoxicology. 2014;45:91-9.

21. Giesbrecht GF, Liu J, Ejaredar M, Dewey D, Letourneau N, Campbell T, et al. Urinary bisphenol a is associated with dysregulation of hpa-axis function in pregnant women: findings from the apron cohort study. Environ Res. 2016;151:689-97.

22. Gitau R, Fisk NM, Glover V. Human fetal and maternal corticotrophin releasing hormone responses to acute stress. Arch Dis Child Fetal Neonatal Ed. 2004;89:F29-32.

23. Glover V, Miles R, Matta S, Modi N, Stevenson J. Glucocorticoid exposure in preterm babies predicts saliva cortisol response to immunization at 4 months. Pediatr Res. 2005:58:1233-7.

24. Granger DA, Hibel LC, Fortunato CK, Kapelewski CH. Medication effects on salivary cortisol: tactics and strategy to minimize impact in behavioral and developmental science. Psychoneuroendocrinology. 2009;34:1437-48. 
25. Gunnar MR, Donzella B. Social regulation of the cortisol levels in early human development. Psychoneuroendocrinology. 2002;27:199-220.

26. Handa RJ, Weiser MJ. Gonadal steroid hormones and the hypothalamopituitary-adrenal axis. Front Neuroendocrinol. 2014;35:197-220.

27. Harley KG, Gunier RB, Kogut K, Johnson C, Bradman A, Calafat AM, et al. Prenatal and early childhood bisphenol a concentrations and behavior in school-aged children. Environ Res. 2013;126:43-50.

28. Health Canada. 2008. Health risk assessment of bisphenol a from food packaging applications. Available: http://www.hc-sc.gc.ca/fn-an/alt_formats/ hpfb-dgpsa/pdf/securit/bpa_hra-ers-eng.pdf [Accessed 21 Mar 2017.

29. Kaplan BJ, Giesbrecht GF, Leung BM, Field CJ, Dewey D, Bell RC, et al. The alberta pregnancy outcomes and nutrition (apron) cohort study: rationale and methods. Matern Child Nutr. 2014;10:44-60.

30. Kitraki E, Nalvarte I, Alavian-Ghavanini A, Ruegg J. Developmental exposure to bisphenol a alters expression and DNA methylation of fkbp5, an important regulator of the stress response. Mol Cell Endocrinol. 2015;417:191-9.

31. Kubo K, Arai O, Omura M, Watanabe R, Ogata R, Aou S. Low dose effects of bisphenol a on sexual differentiation of the brain and behavior in rats. Neurosci Res. 2003:45:345-56.

32. Lee YJ, Ryu HY, Kim HK, Min CS, Lee JH, Kim E, et al. Maternal and fetal exposure to bisphenol a in korea. Reprod Toxicol. 2008;25:413-9.

33. Lewis RC, Meeker JD, Peterson KE, Lee JM, Pace GG, Cantoral A, et al. Predictors of urinary bisphenol a and phthalate metabolite concentrations in mexican children. Chemosphere. 2013;93:2390-8.

34. Lupien SJ, McEwen BS, Gunnar MR, Heim C. Effects of stress throughout the lifespan on the brain, behaviour and cognition. Nat Rev Neurosci. 2009;10:434-45

35. McCarthy AM, Hanrahan K, Kleiber C, Zimmerman MB, Lutgendorf S, Tsalikian E. Normative salivary cortisol values and responsivity in children. Appl Nurs Res. 2009:22:54-62.

36. Morelius E, Theodorsson E, Nelson N. Stress at three-month immunization: Parents' and infants' salivary cortisol response in relation to the use of pacifier and oral glucose. Eur J Pain. 2009;13:202-8.

37. Palanza P, Morellini F, Parmigiani S, Vom Saal FS. Prenatal exposure to endocrine disrupting chemicals: effects on behavioral development. Neurosci Biobehav Rev. 1999;23:1011-27.

38. Palanza P, Howdeshell KL, Parmigiani S, Vom Saal FS. Exposure to a low dose of bisphenol a during fetal life or in adulthood alters maternal behavior in mice. Environ Health Perspect. 2002;110(Suppl 3):415-22.

39. Palanza P, Gioiosa L, Vom Saal FS, Parmigiani S. Effects of developmental exposure to bisphenol a on brain and behavior in mice. Environ Res. 2008;108:150-7.

40. Panagiotidou E, Zerva S, Mitsiou DJ, Alexis MN, Kitraki E. Perinatal exposure to low-dose bisphenol a affects the neuroendocrine stress response in rats. J Endocrinol. 2014;220:207-18.

41. Perera F, Vishnevetsky J, Herbstman JB, Calafat AM, Xiong W, Rauh V, et al. Prenatal bisphenol a exposure and child behavior in an inner-city cohort. Environ Health Perspect. 2012;120:1190-4.

42. Poimenova A, Markaki E, Rahiotis C, Kitraki E. Corticosterone-regulated actions in the rat brain are affected by perinatal exposure to low dose of bisphenol a. Neuroscience. 2010;167:741-9.

43. Prasanth GK, Divya LM, Sadasivan C. Bisphenol-a can bind to human glucocorticoid receptor as an agonist: an in silico study. J Appl Toxicol. 2010;30:769-74.

44. Roen EL, Wang Y, Calafat AM, Wang S, Margolis A, Herbstman J, et al. Bisphenol a exposure and behavioral problems among inner city children at 7-9 years of age. Environmental Research. 2015;142:739-45.

45. Rubin BS, Lenkowski JR, Schaeberle CM, Vandenberg LN, Ronsheim PM, Soto AM. Evidence of altered brain sexual differentiation in mice exposed perinatally to low, environmentally relevant levels of bisphenol a. Endocrinology. 2006;147:3681-91.

46. Schechter NL, Zempsky WT, Cohen LL, McGrath PJ, McMurtry CM, Bright NS. Pain reduction during pediatric immunizations: evidence-based review and recommendations. Pediatrics. 2007:119:e1184-98.

47. Snijder CA, Heederik D, Pierik FH, Hofman A, Jaddoe WW, Koch HM, et al. Fetal growth and prenatal exposure to bisphenol a: the generation $r$ study. Environ Health Perspect. 2013;121:393-8.

48. Stang HJ, Gunnar MR, Snellman L, Condon LM, Kestenbaum R. Local anesthesia for neonatal circumcision. Effects on distress and cortisol response JAMA. 1988;259:1507-11.
49. Thayer KA, Doerge DR, Hunt D, Schurman SH, Twaddle NC, Churchwell MI, et al. Pharmacokinetics of bisphenol a in humans following a single oral administration. Environ Int. 2015;83:107-15.

50. Tollenaar MS, Beijers R, Jansen J, Riksen-Walraven JM, de Weerth C. Maternal prenatal stress and cortisol reactivity to stressors in human infants. Stress. 2011;14:53-65.

51. Vandenberg LN, Hauser R, Marcus M, Olea N, Welshons WV. Human exposure to bisphenol a (bpa). Reprod Toxicol. 2007;24:139-77.

52. Veiga-Lopez A, Kannan K, Liao C, Ye W, Domino SE, Padmanabhan V. Gender-specific effects on gestational length and birth weight by early pregnancy bpa exposure. J Clin Endocrinol Metab. 2015;100:E1394-403.

53. Volkel W, Colnot T, Csanady GA, Filser JG, Dekant W. Metabolism and kinetics of bisphenol a in humans at low doses following oral administration. Chem Res Toxicol. 2002;15:1281-7.

54. Wang J, Sun B, Hou M, Pan X, Li X. The environmental obesogen bisphenol a promotes adipogenesis by increasing the amount of 11 betahydroxysteroid dehydrogenase type 1 in the adipose tissue of children. International journal of obesity (2005). 2013;37:999-1005.

55. Weiser MJ, Handa RJ. Estrogen impairs glucocorticoid dependent negative feedback on the hypothalamic-pituitary-adrenal axis via estrogen receptor alpha within the hypothalamus. Neuroscience. 2009;159:883-95.

56. Welberg LA, Seckl JR. Prenatal stress, glucocorticoids and the programming of the brain. J Neuroendocrinol. 2001;13:113-28.

57. Wolff MS, Engel SM, Berkowitz GS, Ye X, Silva MJ, Zhu C, et al. Prenatal phenol and phthalate exposures and birth outcomes. Environ Health Perspect. 2008;116:1092-7.

58. Wozniak AL, Bulayeva NN, Watson CS. Xenoestrogens at picomolar to nanomolar concentrations trigger membrane estrogen receptor-alphamediated ca2+ fluxes and prolactin release in gh3/b6 pituitary tumor cells. Environ Health Perspect. 2005;113:431-9.

59. Ye X, Kuklenyik Z, Needham LL, Calafat AM. Measuring environmental phenols and chlorinated organic chemicals in breast milk using automated on-line column-switching-high performance liquid chromatography-isotope dilution tandem mass spectrometry. J Chromatogr B Analyt Technol Biomed Life Sci. 2006:831:110-5.

\section{Submit your next manuscript to BioMed Central and we will help you at every step:}

- We accept pre-submission inquiries

- Our selector tool helps you to find the most relevant journal

- We provide round the clock customer support

- Convenient online submission

- Thorough peer review

- Inclusion in PubMed and all major indexing services

- Maximum visibility for your research

Submit your manuscript at www.biomedcentral.com/submit
) Biomed Central 